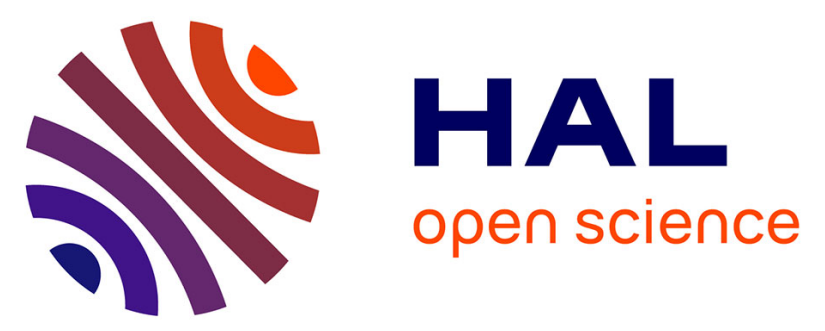

\title{
Effect of substituents on the configurational stability of the stereogenic nitrogen in metal(II) complexes of $\alpha$-amino acid Schiff bases
}

Haibo Mei, Marion Jean, Muriel Albalat, Nicolas Vanthuyne, Christian Roussel, Hiroki Moriwaki, Zizhen Yin, Jianlin Han, Vadim A Soloshonok

\section{To cite this version:}

Haibo Mei, Marion Jean, Muriel Albalat, Nicolas Vanthuyne, Christian Roussel, et al.. Effect of substituents on the configurational stability of the stereogenic nitrogen in metal(II) complexes of $\alpha$-amino acid Schiff bases. Chirality, 2019, 31 (5), pp.401-409. 10.1002/chir.23066 . hal-02514521

\author{
HAL Id: hal-02514521 \\ https://hal.science/hal-02514521
}

Submitted on 23 Mar 2020

HAL is a multi-disciplinary open access archive for the deposit and dissemination of scientific research documents, whether they are published or not. The documents may come from teaching and research institutions in France or abroad, or from public or private research centers.
L'archive ouverte pluridisciplinaire HAL, est destinée au dépôt et à la diffusion de documents scientifiques de niveau recherche, publiés ou non, émanant des établissements d'enseignement et de recherche français ou étrangers, des laboratoires publics ou privés. 


\title{
Effect of substituents on the configurational stability of the stereogenic nitrogen in metal(II) complexes of $\alpha$-amino acid Schiff bases
}

\author{
Mei, H. B. \\ Jean, $M$. \\ Albalat, $\mathrm{M}$. \\ Vanthuyne, N. \\ Roussel, $\mathrm{C}$. \\ Moriwaki, $\mathrm{H}$. \\ Yin, Z. Z. \\ Han, J. L. \\ Soloshonok, V. A.
}

\begin{abstract}
Herein, we report a general method for quantitative measurement of the configurational stability of the stereogenic nitrogen coordinated to $\mathrm{M}$ (II) in the corresponding square planar complexes. This stereochemical approach is quite sensitive to steric and electronic effects of the substituents and shown to work well for $\mathrm{Ni}(\mathrm{II}), \mathrm{Pd}(\mathrm{II})$, and $\mathrm{Cu}(\mathrm{II})$ complexes. Structural simplicity of the compounds used, coupled with high sensitivity and reliability of experimental procedures, bodes well for application of this approach in evaluation of chemical stability and stereochemical properties of newly designed chiral ligands for general asymmetric synthesis of tailor-made amino acids.
\end{abstract}

\section{1 | INTRODUCTION}

Tailor-made amino acids (AAs), ${ }^{1}$ are essential structural features of numerous modern pharmaceuticals. ${ }^{2}$ Application of AA residues in drug design allows for fairly accurate 3-D positioning of pharmacophoric moieties and mimicking the targeted biogenic peptide-receptor interactions. ${ }^{3}$ Thus, over the past decade, about $20 \%$ of newly introduced drugs contained at least one tailor-made AA residue. ${ }^{2}$ Consequently, the development of synthetic methodology for preparation of tailor-made AAs is currently in very high demand. ${ }^{4}$ Following our long-standing interest in synthesis of sterically constrained ${ }^{5}$ and fluorine-containing AAs, ${ }^{6}$ we were actively contributing to the general asymmetric synthesis of $\alpha$-AAs via $\mathrm{Ni}(\mathrm{II})$ complexes of AA Schiff bases (Scheme 1). ${ }^{7}$ 


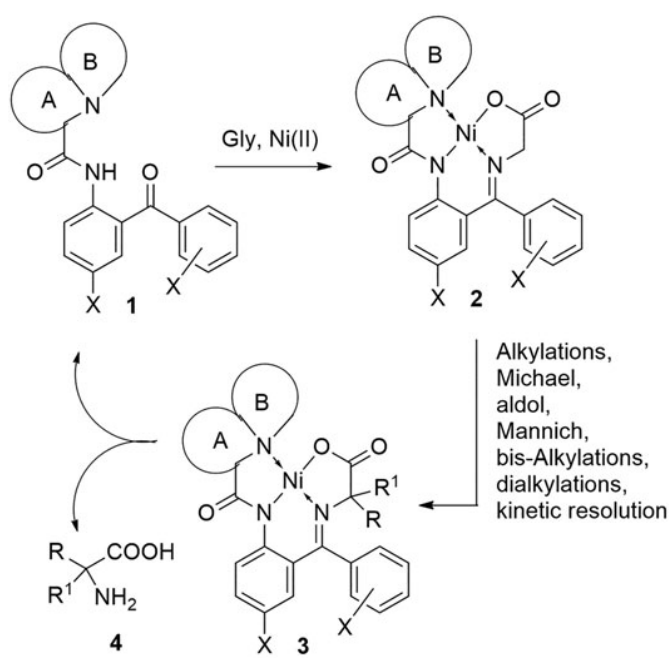

SCHEME 1 General asymmetric synthesis of $\alpha$-amino acids via homologation of Gly Schiff base Ni(II) complexes 2, bearing stereochemical information on structural moieties A and/or B

As demonstrated by our and other research groups, homologation of chiral nucleophilic glycine equivalents 2 via, for example, alkylations, Michael, aldol, and Mannich addition reactions, offers a general approach to various structurally and functionally varied tailormade AAs. ${ }^{8}$ Disassembly of homologation products $\mathbf{3}$ is conducted under simple acidic conditions allowing isolation of the target AAs $\mathbf{4}$ along with a complete recovery of chiral ligands $\mathbf{1}$, as well as the $\mathrm{Ni}(\mathrm{II})$, underscoring the practicality of this methodology. Using modular approach $^{9}$ for the design of ligands $\mathbf{1}$, numerous glycine complexes $\mathbf{2}$ were prepared with the aim to improve the synthetic value and scalability of this methodology. ${ }^{8}$ However, the rational design of better performing ligands and the corresponding $\mathrm{Ni}(\mathrm{II})$ complexes of AA Schiff bases is still hindered by incomplete understanding of the effects of ligands $\mathbf{1}$ structure on the stability and reactivity of target complexes $\mathbf{2}$. For example, as conceptually shown in Scheme 1, structural areas A, B as well as substituents X, can bear aliphatic, aromatic, electronwithdrawing/donating moieties imparting the strength of the nitrogen-nickel coordination bond, chelate rings and, therefore, the overall stability of the $\mathrm{Ni}(\mathrm{II})$ complexes of this type. Accordingly, we envisioned that the development of viable approaches for quantitative measurement of nitrogen-metal bond stability would have a profound impact on

the advancement of structural design of $\mathrm{Ni}(\mathrm{II})$ complexes $\mathbf{2}$ and their synthetic applications. Here, we report an innovative approach for experimental probing of the nitrogen-metal bond coordination energies using model compounds derived from metal(II) complexes of glycine Schiff base. The key feature of this work is the direct probing the configurational stability of stereogenic nitrogen as a function of stereo/electronic properties of the N-ligand substituents as well as the nature coordinating metal $\mathrm{M}(\mathrm{II})$.

\section{2 | MATERIALS AND METHODS}

\section{1 | General information}

All commercial reagents were used without additional purification unless otherwise specified. Solvents were purified and dried according to standard methods prior to use. All experiments were monitored by thin layer chromatography (TLC) using ultraviolet (UV) light as visualizing agent. Column chromatography was performed using silica gel 60 (300-400 mesh). ${ }^{1} \mathrm{H}$ NMR (400 $\mathrm{MHz}$ ) and ${ }^{13} \mathrm{C}$ NMR (101 MHz) were measured on Bruker AVANCE III-400 spectrometer. Melting points are uncorrected. Values of optical rotation were measured on Rudolph Automatic Polarimeter A21101 at the wavelength of the sodium D-line $(589 \mathrm{~nm})$. Infrared spectra were obtained on Bruker Vector 22 in $\mathrm{KBr}$ pellets. HRMS were recorded on a LTQ-Orbitrap XL (Thermofisher, Waltham, Massachusetts).

\section{2 | General procedures for the reaction between o-amino-benzophenones 7 and bromoacetyl bromide}

A solution of bromoacetyl bromide (46 $\mathrm{mmol})$ in acetonitrile ( $2 \mathrm{~mL} / 1 \mathrm{~g}$ of bromoacetyl bromide) was slowly added to a slurry of 2-aminobenzophenone $(20.4 \mathrm{mmol})$ and potassium carbonate $(102.2 \mathrm{mmol})$ in acetonitrile. The reaction was stirred at ambient temperature for 1 hour, and upon completion (monitored by TLC), the acetonitrile was evaporated under vacuum. Fifty milliliter of water was then added to the crude mixture and extracted with dichloromethane $50 \mathrm{~mL}$ for three times. The organic portions were combined and dried over anhydrous $\mathrm{Na}_{2} \mathrm{SO}_{4}$. The solvent was evaporated to give the crude product $\mathbf{8}$, which was purified by flash chromatography.

\section{3 | General procedures for preparation of 9}

To a slurry of 8 (1 equiv) and potassium carbonate (1.2 equiv) in acetonitrile was added the corresponding amine (1.1 equiv). The reaction was allowed to proceed for 2 hours at $60^{\circ} \mathrm{C}$ to $70^{\circ} \mathrm{C}$ (monitored by TLC) before the reaction mixture was concentrated under vacuum. Water was added to the viscous liquid, followed by extraction with dichloromethane. The organic portions were 
combined and dried with magnesium sulfate. The solvent was evaporated to give the crude product $\mathbf{9}$, which was purified by flash chromatography.

\section{4 | General procedures for preparation of $\mathrm{Ni}$ (II) complex (10a-h)}

An oven-dried reaction vial containing $9(0.2 \mathrm{mmol})$, glycine (5 equiv), nickel nitrate hexahydrate ( 2 equiv), and $\mathrm{K}_{2} \mathrm{CO}_{3}$ was evacuated and purged with argon three times. Then, $\mathrm{MeOH}(4 \mathrm{~mL})$ as solution was added via syringe at ambient temperature. Then, the reaction mixture was stirred for 8 hours at ambient temperature, and then the reaction was quenched with $\mathrm{H}_{2} \mathrm{O}(5 \mathrm{~mL})$. The organic layer was removed, and the aqueous layer was extracted with DCM $(2 \times 5 \mathrm{~mL})$. The combined organic layers were washed with $\mathrm{H}_{2} \mathrm{O}(2 \times 10 \mathrm{~mL})$ and brine $(1 \times 10 \mathrm{~mL})$ and dried over anhydrous $\mathrm{Na}_{2} \mathrm{SO}_{4}$. The solvent was evaporated to give the crude product $\mathbf{1 0}$, which was purified by flash chromatography.

\section{5 | General procedures for preparation of Pd(II) complex (10i)}

An oven-dried reaction vial containing 9 ( $\mathrm{N}-(2-$ benzoylphenyl)-2-(isopropylamino)acetamide) mmol), glycine (5 equiv), $\mathrm{PdCl}_{2}$ (2 equiv), and $\mathrm{NaOH}(7$ equiv) was evacuated and purged with argon three times. Then, $\mathrm{MeOH}(4 \mathrm{~mL})$ as solvent were added via syringe at ambient temperature. Then, the reaction mixture was stirred for 4 hours at $60^{\circ} \mathrm{C}$ to $70^{\circ} \mathrm{C}$, and then the reaction was quenched with $\mathrm{AcOH}(1 \mathrm{~mL})$. The organic layer was removed, and the aqueous layer was extracted with DCM $(2 \times 5 \mathrm{~mL})$. The combined organic layers were washed with $\mathrm{H}_{2} \mathrm{O}(2 \times 10 \mathrm{~mL})$ and brine $(1 \times 10 \mathrm{~mL})$ and dried over anhydrous $\mathrm{Na}_{2} \mathrm{SO}_{4}$. The solvent was evaporated to give the crude product, which was purified by flash chromatography.

\subsection{General procedures for preparation of $\mathrm{Cu}(\mathrm{II})$ complex (10j)}

An oven-dried reaction vial containing $9(0.2 \mathrm{mmol})$, glycine (5 equiv), $\mathrm{CuSO}_{4} \cdot 5 \mathrm{H}_{2} \mathrm{O}$ (2 equiv), and $\mathrm{KOH}$ (7 equiv) was evacuated and purged with argon three times. Then, $\mathrm{MeOH}(4 \mathrm{~mL})$ as solvent were added via syringe at ambient temperature. Then, the reaction mixture was stirred for 8 hours at ambient temperature, and then the reaction was quenched with $\mathrm{H}_{2} \mathrm{O}(5 \mathrm{~mL})$. The organic layer was removed, and the aqueous layer was extracted with DCM $(2 \times 5 \mathrm{~mL})$. The combined organic layers were washed with $\mathrm{H}_{2} \mathrm{O}(2 \times 10 \mathrm{~mL})$ and brine $(1 \times 10 \mathrm{~mL})$ and dried over anhydrous $\mathrm{Na}_{2} \mathrm{SO}_{4}$. The solvent was evaporated to give the crude product $\mathbf{1 0 j}$, which was purified by flash chromatography.

\section{7 | Chiral chromatography}

Analytical columns ( 250 x $4.6 \mathrm{~mm}, 5$ microns), Chiralpak IA, IB, IC, ID, and (S,S)-Ulmo were thermostated and used to optimize the enantiomer separations, to determine ee and for dynamic chiral HPLC. Preparative columns ( $250 \times 10 \mathrm{~mm}, 5$ microns) were used to collect the enantiomers. The resulting solutions were kept in an ice bath during the separative process and below $10^{\circ} \mathrm{C}$ during the evaporation.

\section{3 | RESULTS AND DISCUSSION}

Recently, we demonstrated that Ni(II)-complex $\mathbf{5}$ (Scheme 2) can be successfully used to assess its configurational stability of the stereogenic nitrogen via HPLC assisted kinetic racemization experiments. ${ }^{10 a}$ Our preliminary studies ${ }^{10}$ served as a convincing demonstration of the viability of the chosen HPLC-based approach for working with $\mathrm{Ni}(\mathrm{II})$ complexes of AA Schiff bases. In particular, for $\mathrm{Ni}(\mathrm{II})$ complex $\mathbf{5}$, we reported that the configurational stability of the $\mathrm{Ni}(\mathrm{II})$-coordinated nitrogen significantly depends on the solvent used for the experiments. Thus, in strongly coordinating solvents, ${ }^{11}$ such as water, acetonitrile, or alcohols, the configurational stability of the stereogenic nitrogen is rather low with the $t^{1} / 2$ of racemization ranging from greater than 5 minutes to several hours. In sharp contrast, in solvents such as chloroform, ethyl acetate, or toluene, the values for racemization $t^{1} \frac{1}{2}$ (from 6-90 years) show some remarkable, synthetically useful configurational stability. ${ }^{12}$

While reported in the previous work, ${ }^{10 \mathrm{a}}$ data provided detailed and instructive understanding of the chiral nitrogen configurational stability in relationship to the reaction solvent, the effect of substituents on the nitrogen as well as the coordinating metal remained totally unknown. Thus, drawing inspiration from the success of

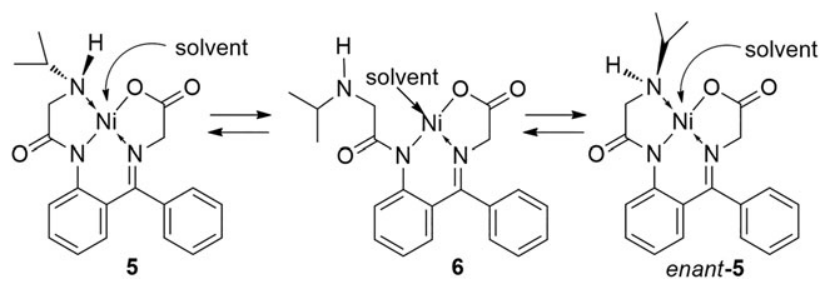

SCHEME 2 Racemization of $\mathrm{Ni}(\mathrm{II})$ complex $\mathbf{5}$, possessing stereogenic nitrogen, via discoordinated intermediate $\mathbf{6}$ 
the previous study, ${ }^{10 a}$ we designed a new set of the stereochemical models presented in Scheme 3.

Synthesis of compounds 8-10a-j was performed similar to general procedures described earlier.9, 10a, 13 Thus, commercially available $o$-amino-benzophenones 7 were chemo-selectively acylated using bromoacetyl bromide in acetonitrile to furnish bromo-amides $\mathbf{8}$. Isolated and purified by column chromatography compounds $\mathbf{8}$ were reacted with the corresponding secondary of tertiary amines in the presence of Hünig's base ${ }^{12}$ to prevent the quaternization of the amino functionality. Thus, prepared ligands 9 were heated in methanol with glycine, $\mathrm{K}_{2} \mathrm{CO}_{3}$, $\mathrm{NaOH}$, or $\mathrm{KOH}$ (depending on the metal used), as a base, and source of M(II) ions to furnish racemic M(II) complexes of glycine Schiff bases $(R / S)-\mathbf{1 0 a}-\mathbf{j}$. Compounds $(R / S)-\mathbf{1 0 a}-\mathbf{j}$ were purified by column chromatography and fully characterized.

The present study was initiated using available to us fully automated screening unit for chiral separation

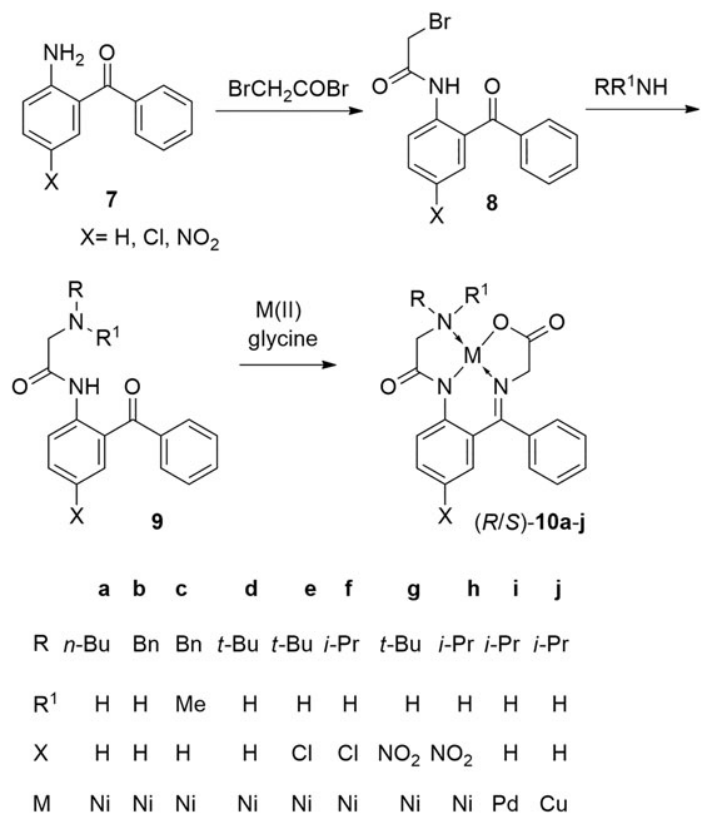

SCHEME 3 Synthesis of ligands 9 and chiral glycine Schiff base $\mathrm{M}(\mathrm{II})$ complexes 10a-j bearing stereogenic nitrogen conditions (chiral stationary phases, solvents, temperature, chiroptical detection) equipped with five different columns: Pirkle-type $((S, S)$-Ulmo), cellulose carbamates (Chiralpak IB and IC), and amylose carbamates (Chiralpak IA and ID), followed by meticulous optimization of the separation conditions for each individual compound. We decided to begin our study with $\mathbf{1 0 a}$ (Figure 1) containing $\mathrm{NH}$ function and linear alkyl $N-n$-Bu group, as the simplest type of substitution on the stereogenic nitrogen. After a series of chiral chromatographic experiments, we found that reasonably good separation of enantiomers 10a can be achieved on Chiralpak IA column with amylose carbamate stationary phase, using ethanol as an eluent. The HPLC chart of two baseline-separated enantiomers 10a, conducted under the optimized conditions, is presented in Figure 1.

Using the optimized separation conditions, we conducted preparative separation of enantiomers 10a. Interestingly, while enantiomers (+)- and (-)-10a were cleanly separated, after the solvent evaporation, the enantiomeric purity of both (+)- and (-)-10a was about $90 \%$ ee, clearly indicating partial racemization during the isolation procedure. Thus, using the enantiomerically enriched samples, we performed the enantiomerization (racemization) energy barriers study. An enantioenriched sample was diluted in ethanol, the solution was thermostated at $22^{\circ} \mathrm{C}$, and its enantiomeric excess was measured by chiral chromatography every 10 minutes for 1 hour. The first-order kinetic line for enantiomerization was drawn with an excellent correlation coefficient. The rate of enantiomerization was deduced from the slope of the first-order kinetic line and gave the following data: $\mathrm{k}_{\text {enantiomerisation }}=1 \cdot 15 \cdot 10^{-4}$ $\mathrm{s}^{-1}\left(22^{\circ} \mathrm{C}\right.$, ethanol); $\Delta \mathrm{G}^{\neq}=94.5 \mathrm{~kJ} / \mathrm{mol}\left(22^{\circ} \mathrm{C}\right.$, ethanol). These data indicated that $t_{1 / 2}$ racemization for enantiomers 10a is only 50 minutes at $22^{\circ} \mathrm{C}$ in ethanol. In other words, the racemization occurs relatively easy at ambient temperature; yet, the configurational stability of $\mathbf{1 0 a}$ is sufficient enough to achieve the goal of this research project. For the reference, the data reported for the $i$-propyl containing complex 5 was as follows: $\mathrm{k}_{\text {enantiomerization }}=$

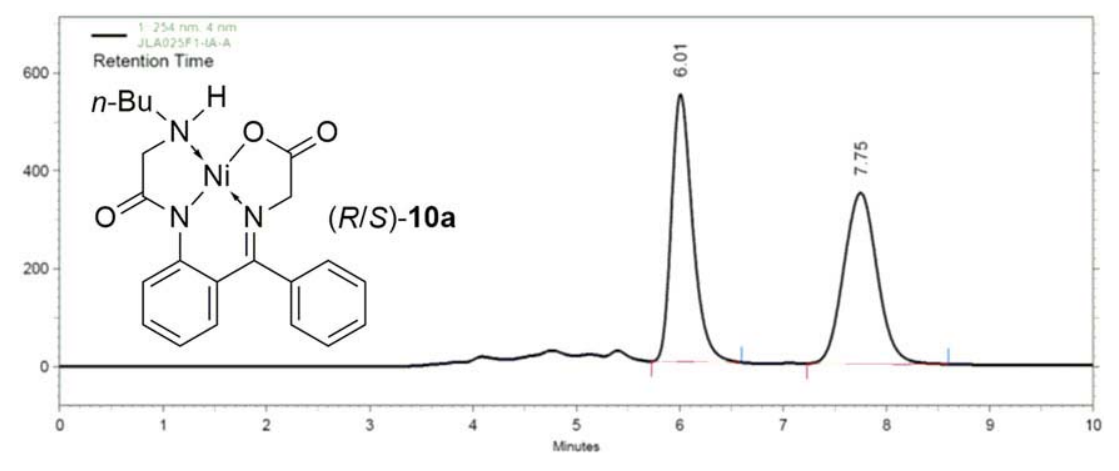

FIGURE 1 Separation of enantiomers of compound 10a on Chiralpak IA column; ethanol, $0.8 \mathrm{~mL} / \mathrm{min}$, UV $254 \mathrm{~nm}$, $25^{\circ} \mathrm{C}$ 


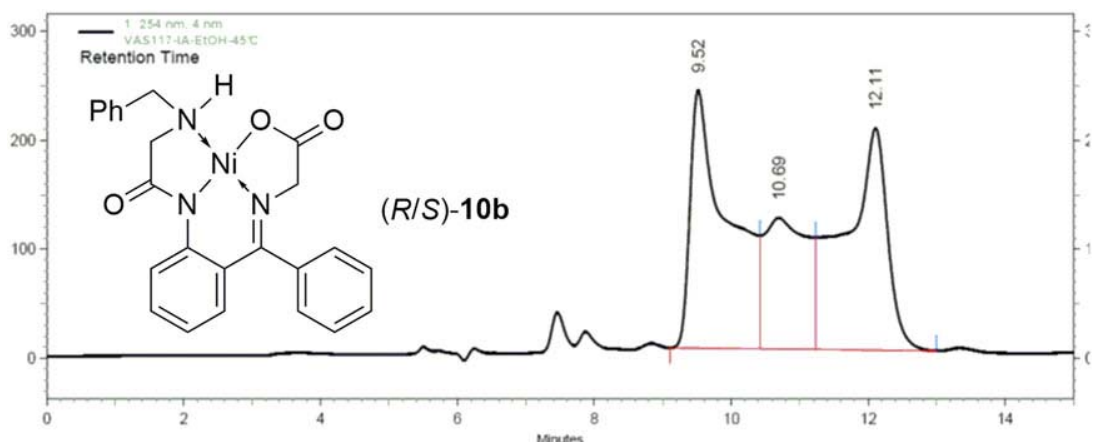

FIGURE 2 Separation of enantiomers 10b and their on-line racemization; Chiralpak IA column; ethanol, $0.5 \mathrm{~mL} /$ min, ultraviolet (UV) $254 \mathrm{~nm}$, and CD $390 \mathrm{~nm}, 45^{\circ} \mathrm{C}$

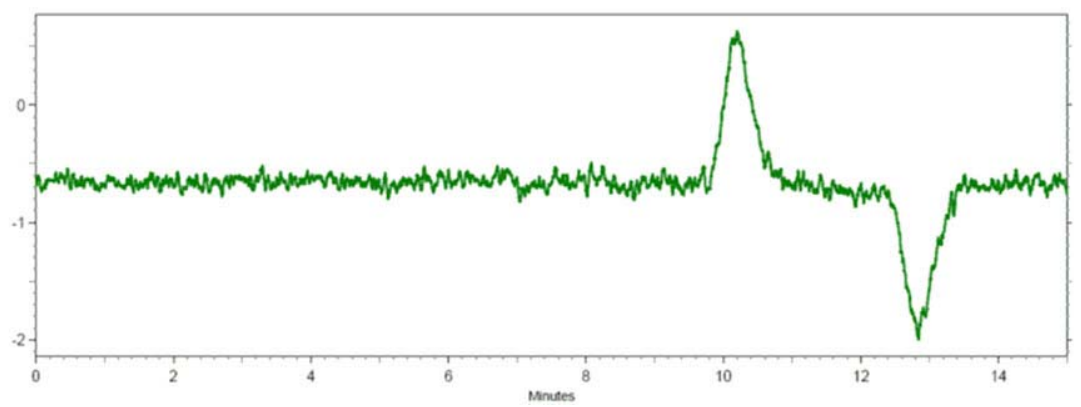

$9.0510^{-6} \mathrm{~s}^{-1}\left(22^{\circ} \mathrm{C}\right.$, ethanol) with the $\Delta \mathrm{G}^{\neq}=100.8(\mathrm{~kJ} /$ mol) indicated that $t_{1 / 2}$ racemization for enantiomers 5 is 7 hours, indicating some noticeable effect of $n$-Bu vs $i$-Pr goups on the configurational stability of the stereogenic nitrogen.

Building on this progress, we proceeded with generalization of this approach by using compound 10b (Figure 2) containing the same NH functionally, but with the benzyl group instead of the linear alkyl substituent. We found that separation of enantiomers $\mathbf{1 0 b}$ can also be achieved on Chiralpak IA column under the same condition as we used for separation of enantiomers of 10a (see the Data S1).

In this case, however, the enantiomers 10b were not isolated by preparative HPLC, as we chose to try another "online" technique to study the racemization kinetics. ${ }^{10 \mathrm{c}}$ Thus, the racemization was evidenced during the HPLC analysis at higher temperature, $45^{\circ} \mathrm{C}$, by the occurrence of a "plateau" between both enantiomers (Figure 2). Each peak with a chiroptical sign corresponds to enantiomers that have not undergone any enantiomerization in the column and the plateau between the two peaks corresponds to molecules that have undergone one or several

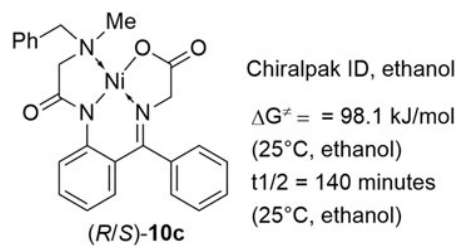

FIGURE 3 Configurational stability of complex 10c enantiomerizations. According to the Trapp-Schurig's Equation $^{14}$ developed for dynamic chiral HPLC, the enantiomerization barrier was calculated from chromatographic parameters, as retention times and height of the plateau. The experiments were conducted at two different temperatures and revealed the following kinetic data, at $35^{\circ} \mathrm{C}: \mathrm{k}_{\text {enantiomerisation }}=4.61 .10^{-4} \mathrm{~s}^{-1}\left(35^{\circ} \mathrm{C}\right.$, ethanol $)$, $\Delta \mathrm{G}^{\neq}=95.2 \mathrm{~kJ} / \mathrm{mol}\left(35^{\circ} \mathrm{C}\right.$, ethanol); and at $45^{\circ} \mathrm{C}$ : $\mathrm{k}_{\text {enantiomerisation }}=1.07 \cdot 10^{-3} \mathrm{~s}^{-1}\left(45^{\circ} \mathrm{C}\right.$, ethanol $), \Delta \mathrm{G}^{\neq}=$ $96.2 \mathrm{~kJ} / \mathrm{mol}\left(45{ }^{\circ} \mathrm{C}\right.$, ethanol). Accordingly, the data recorded for enantiomers of $\mathbf{1 0 b}$ is $\mathrm{t}_{1 / 2}=30$ minutes $\left(25^{\circ} \mathrm{C}\right.$, ethanol), which is quite comparable with the data obtained for NH- $n$-Bu containing complex 10a.

Another example of structural generality of this approach is presented by the example of complex 10c (Figure 3) containing tertiary amino functionality. In this case, the best baseline separation of the enantiomers was achieved on Chiralpak ID column (Rs 1.97); see Data S1 for the HPLC charts and details.
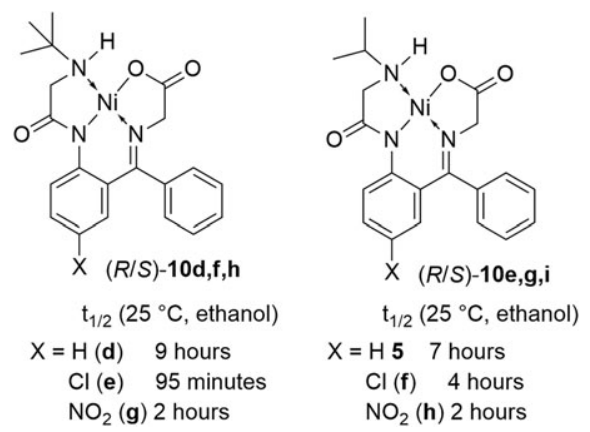

FIGURE 4 Configurational stability of complex $\mathbf{1 0}$ 
TABLE 1 Kinetic data (in ethanol) for racemization of complexes 10d-h

\begin{tabular}{|c|c|c|c|}
\hline Complex & $\mathbf{k}_{\text {enantiomerization }}$ & $\Delta \mathbf{G}^{\neq}$ & $t_{1 / 2}$ \\
\hline 10d & $\begin{array}{c}6.64 .10^{-6} \mathrm{~s}^{-1} \\
\left(22^{\circ} \mathrm{C}\right)\end{array}$ & $\begin{array}{c}101.5 \mathrm{~kJ} / \mathrm{Mol} \\
\left(22^{\circ} \mathrm{C}\right)\end{array}$ & $\begin{array}{l}14.5 \text { hours } \\
\left(22^{\circ} \mathrm{C}\right)\end{array}$ \\
\hline 5 & $\begin{array}{c}1.62 .10^{-5} \mathrm{~s}^{-1} \\
\left(22^{\circ} \mathrm{C}\right)\end{array}$ & $\begin{array}{l}99.3 \mathrm{~kJ} / \mathrm{Mol} \\
\left(22^{\circ} \mathrm{C}\right)\end{array}$ & $\begin{array}{l}6 \text { hours } \\
\left(22^{\circ} \mathrm{C}\right)\end{array}$ \\
\hline $10 \mathrm{e}$ & $\begin{array}{c}4.04 .10^{-5} \mathrm{~s}^{-1} \\
\left(22^{\circ} \mathrm{C}\right)\end{array}$ & $\begin{array}{l}97.1 \mathrm{~kJ} / \mathrm{Mol} \\
\quad\left(22^{\circ} \mathrm{C}\right)\end{array}$ & $\begin{array}{l}2.4 \text { hours } \\
\left(22^{\circ} \mathrm{C}\right)\end{array}$ \\
\hline $10 f$ & $\begin{array}{c}1.63 .10^{-5} \mathrm{~s}^{-1} \\
\left(22^{\circ} \mathrm{C}\right)\end{array}$ & $\begin{array}{c}99.3 \mathrm{~kJ} / \mathrm{Mol} \\
\left(22^{\circ} \mathrm{C}\right)\end{array}$ & $\begin{array}{l}6 \text { hours } \\
\left(22^{\circ} \mathrm{C}\right)\end{array}$ \\
\hline $10 \mathrm{~g}$ & $\begin{array}{c}2.22 .10^{-5} \mathrm{~s}^{-1} \\
\left(19^{\circ} \mathrm{C}\right)\end{array}$ & $\begin{array}{l}97.5 \mathrm{~kJ} / \mathrm{Mol} \\
\quad\left(19^{\circ} \mathrm{C}\right)\end{array}$ & $\begin{array}{c}4.3 \text { hours } \\
\left(19^{\circ} \mathrm{C}\right)\end{array}$ \\
\hline $10 \mathrm{~h}$ & $\begin{array}{l}2.22 .10^{-5} \mathrm{~s}^{-1} \\
\quad\left(19^{\circ} \mathrm{C}\right)\end{array}$ & $\begin{array}{c}97.5 \mathrm{~kJ} / \mathrm{Mol} \\
\left(19^{\circ} \mathrm{C}\right)\end{array}$ & $\begin{array}{c}4.3 \text { hours } \\
\left(19^{\circ} \mathrm{C}\right)\end{array}$ \\
\hline
\end{tabular}

Enantiomers of 10c were separated by preparative chromatography on Chiralpak ID column and remained stereochemically intact ( $>98 \%$ ee) during isolation and solvents evaporation, indicating some higher configurational stability, as compared with $\mathrm{NH}-n$-Bu derivative 10a. Indeed, the racemization and first-order kinetics experiments revealed that in this case, the $\mathrm{k}_{\text {enantiomerisation }}$ $=4.11 .10^{-5} \mathrm{~s}^{-1}\left(25^{\circ} \mathrm{C}\right.$, ethanol $) ; \Delta \mathrm{G}^{\neq}=98.1 \mathrm{~kJ} / \mathrm{mol}$ $\left(25^{\circ} \mathrm{C}\right.$, ethanol). These data correspond to $\mathrm{t}_{1 / 2}=140$ minutes $\left(25^{\circ} \mathrm{C}\right.$, ethanol), which is noticeable greater as compared with $\mathrm{NH}$ type complexes $\mathbf{1 0 a}$ and $\mathbf{1 0 b}$.

The reason for the observed higher configurational stability of 10c over 10a,b can be explained by the electrondonating effect of the methyl group (vs H) and/or the overall steric bulk of the tertiary amine moiety (vs secondary amino group). This line of considerations prompted us to study complexes 10d,e,g bearing bulky $t$ $\mathrm{Bu}$ and new derivatives 10f,h containing $i$-Pr groups (Figure 4).

Furthermore, we prepared a series of chloro- 10e,f and nitro-derivatives $\mathbf{1 0} \mathbf{g}, \mathbf{h}$, bearing these substituents in the para-position to the $\mathrm{Ni}$ (II)-coordinated amide nitrogen (Figure 4), to briefly explore the electronic factors. For each of these five compounds 10d-h, we optimized the chiral HPLC resolution conditions allowing for a clean baseline separation of the corresponding enantiomers. Thus, the following stationary phases were found optimal: Chiralpak ID for 10d, Chiralpak IC for 10,e,g,h, and Chiralpak IB for $\mathbf{1 0} \mathbf{f}$. In each case, the separation of enantiomers were successfully reproduced on preparative scale providing approximately $10 \mathrm{mg}$ of the enantiomerically pure/enriched material to perform the kinetic studies. The racemization in each case was studied as described above for complexes 10a and 10c, following first-order kinetics experiments. The data obtained are summarized in Figure 4 and Table 1.

While the number of examples (eight complexes 10a-h and 5) is relatively small, one can still notice a clear trend that steric effects on the amino group have very minor effect on the stability of these $\mathrm{Ni}$ (II) complexes of glycine Schiff base. By contrast, the electronic effects are of a much greater role as it follows from the cases of alkyl substitution on the nitrogen as well as in the derivatives with the para-substituents on the aromatic ring. Though these trends could be anticipated on the basis of general knowledge about stability of the coordinated compounds, ${ }^{15}$ the developed method provides the previously
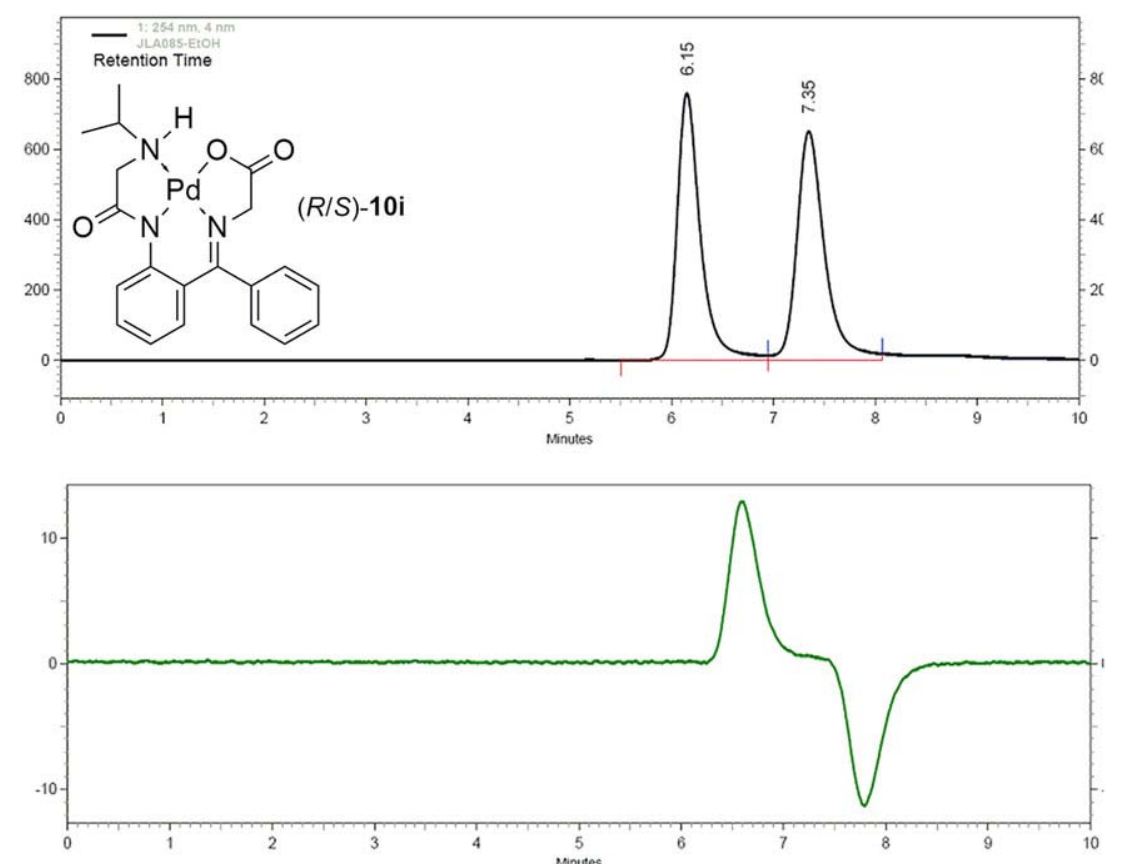

FIGURE 5 Separation of enantiomers of complex 10i on Chiralpak IA; (ethanol, $0.8 \mathrm{~mL} / \mathrm{min}$, UV $254 \mathrm{~nm}$ and CD $390 \mathrm{~nm}$ ) 
FIGURE 6 Separation of enantiomers of complex 10j on Chiralpak IB (ethanol, $0.8 \mathrm{~mL} / \mathrm{min}, \mathrm{UV} 254 \mathrm{~nm}, 25^{\circ} \mathrm{C}$ ) and the online racemization kinetics

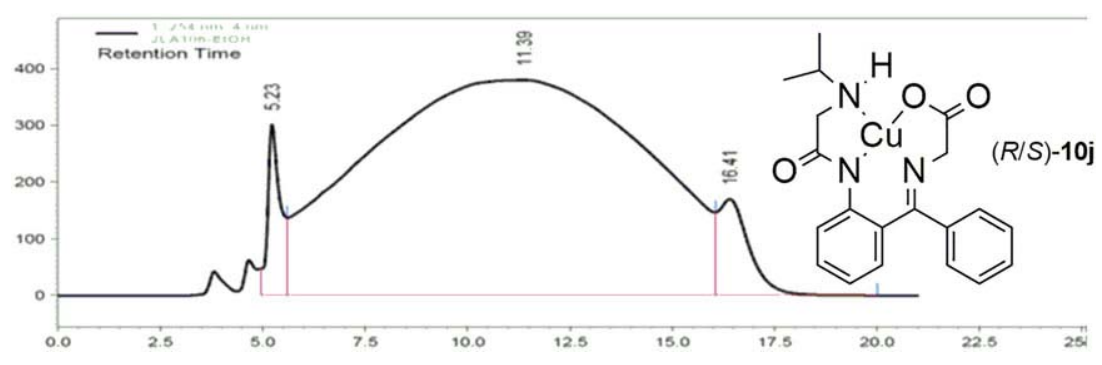

unavailable quantitative assessment of the $\mathrm{N}-\mathrm{Ni}(\mathrm{II})$ coordination strength.

Finally, to show the value of these stereochemical models for greater potential general applications in areas related to $\mathrm{N}$-metal coordination, we decided to measure the stability of $\mathrm{N}-\mathrm{Pd}(\mathrm{II})$ and $\mathrm{N}-\mathrm{Cu}$ (II) bonds. To this end, we prepared (Scheme 3) the corresponding complexes 10i and 10j (Figures 5 and 6, respectively). As one can see from Figure 5, very clean baseline separation of enantiomers of 10i was achieved on Chiralpak IA using ethanol as an eluent.

Enantiomers 10i were also separated on the preparative scale ( $3 \mathrm{mg}$ each) and isolated in enantiomerically pure form. Investigation of the kinetics of their racemization gave the following data: $\mathrm{k}_{\text {enantiomerisation }}=9.55 .10^{-6} \mathrm{~s}$ ${ }^{-1}$ ( $25^{\circ} \mathrm{C}$, ethanol); $\Delta \mathrm{G}^{\neq}=101.7 \mathrm{~kJ} / \mathrm{mol}\left(25^{\circ} \mathrm{C}\right.$, ethanol); $\mathrm{t}_{1 / 2}=10$ hours $\left(25^{\circ} \mathrm{C}\right.$, ethanol). Comparison of the data obtained for the complex 10e, containing the same ligand, we can confirm that the $\mathrm{N}-\mathrm{Pd}$ (II) bond is noticeably more stable (7 vs 10 hours). While the greater stability of 10i over 10e can be rather expected, ${ }^{15}$ the quantitative difference was obtained for the first time in this work. By contrast, $\mathrm{Cu}$ (II) complex $\mathbf{1 0} \mathbf{j}$ was found to be less stable, as it follows from the online racemization experiments (Figure 6). The enantiomerization of $10 \mathrm{j}$ during chiral chromatography at $25^{\circ} \mathrm{C}$ is evidenced by the profile of the chromatogram. Most of the molecules enantiomerize during the analysis, giving a very broad central peak.

The following data: kenantiomerisation $=4.62 .10^{-3} \mathrm{~s}-1$ ( $25^{\circ} \mathrm{C}$, ethanol); $\Delta \mathrm{G} \neq=86.4 \mathrm{~kJ} / \mathrm{mol}\left(25^{\circ} \mathrm{C}\right.$, ethanol); $\mathrm{t}_{1 / 2}$ $=1.25$ minutes $\left(25^{\circ} \mathrm{C}\right.$, ethanol) indicate that $\mathrm{Cu}$ (II) complex $\mathbf{1 0} \mathbf{j}$ is significantly less stable as compared with Ni(II) (7 hours) 10e and Pd(II) (10 hours) 10i. Again, while this conclusion can be anticipated, ${ }^{15}$ the quantitative difference is reported here for the first time.

\section{4 | CONCLUSION}

In conclusion, we successfully designed and realized innovative stereochemical models for quantitative measurement of the configurational stability of the stereogenic nitrogen coordinated to $\mathrm{M}(\mathrm{II})$ in the corresponding square planar complexes. These stereochemical models are sensitive to steric as well as electronic effects and proven to work well for $\mathrm{Ni}(\mathrm{II}), \mathrm{Pd}(\mathrm{II})$, and $\mathrm{Cu}(\mathrm{II})$. Structural simplicity of the model compounds, coupled with high sensitivity and reliability of experimental procedures bodes well for further development and application of this approach.

1. For the definition of tailor-made amino acids, see:a)Soloshonok VA, Cai C, Hruby VJ, Meervelt LV, Mischenko N. Stereochemically defined C-substituted glutamic acids and their derivatives. 1. An efficient asymmetric synthesis of (2S,3S)-3methyl- and -3-Trifluoromethylpyroglutamic acids. Tetrahedron. 1999;55(41):12031-12044. b)Soloshonok VA, Cai C, Hruby VJ, Meervelt LV. Asymmetric synthesis of novel highly sterically constrained (2S,3S)-3-methyl-3-trifluoromethyl- and (2S,3S,4R)-3-trifluoromethyl-4-methylpyroglutamic acids. Tetrahedron. 1999;55(41):12045-12058.

2. a)Ma JS. Unnatural amino acids in drug discovery. Chim Oggi. 2003;21:65-68. b)Hodgson DRW, Sanderson JM. The synthesis of peptides and proteins containing non-natural amino acids. Chem Soc Rev. 2004;33(7):422-430. c)Sato T, Izawa K, Aceña JL, Liu H, Soloshonok VA. Tailor-made $\alpha$-amino acids in pharmaceutical industry: synthetic approaches to (1R,2S)-1Amino-2-vinylcyclopropane-1-carboxylic acid (vinyl-ACCA). Eur J Org Chem. 2016;2016(16):2757-2774. d)Soloshonok VA, Izawa K (Eds). Asymmetric Synthesis and Application of AlphaAmino Acids. ACS Symposium Series \#1009. New York: Oxford University Press; 2009.

3. a)Gibson SE, Guillo N, Tozer MJ. Towards control of $\chi$-space: conformationally constrained analogues of Phe, Tyr, Trp and his. Tetrahedron. 1999;55(3):585-615. b)Soloshonok VA. Highly diastereoselective Michael addition reactions between 
nucleophilic glycine equivalents and $\beta$-substituted- $\alpha, \beta$ unsaturated carboxylic acid derivatives: a general approach to the stereochemically defined and sterically $\chi$-constrained $\alpha$ amino acids. Curr Org Chem. 2002;6(4):341-364. c)Urman S, Gaus K, Yang Y, et al. The constrained amino acid $\beta$-Acc confers potency and selectivity to integrin ligands. Angew Chem Int Ed. 2007;46(21):3976-3978. d)Mikhailiuk P, Afonin KS, Chernega AN, et al. Conformationally rigid trifluoromethyl-substituted $\alpha$-amino acid designed for peptide structure analysis by solidstate19F NMR spectroscopy. Angew Chem Int Ed. 2006;45(34):5659-5661.

4. For recent reviews, see:a)Kukhar VP, Sorochinsky AE, Soloshonok VA. Practical synthesis of fluorine-containing $\alpha$ and $\beta$-amino acids: recipes from Kiev, Ukraine. Future Med Chem. 2009;1(5):793-819. b)Soloshonok VA, Sorochinsky AE. Practical methods for the synthesis of symmetrically $\alpha, \alpha-$ Disubstituted- $\alpha$-amino acids. Synthesis. 2010;2010(14):2319-2344. c)Kim Y, Park J, Kim MJ. Dynamic kinetic resolution of amines and amino acids by enzymemetal cocatalysis. ChemCatChem. 2011;3(2):271-277. d)Mikami K, Fustero S, Sánchez-Roselló M, Aceña JL, Soloshonok VA. Sorochinsky a E synthesis of fluorine containing $\beta$-amino acids. Synthesis. 2011;2011:3045-3079. e)Wang J, Zhang L, Jiang H, Chen K, Liu H. Application of nickel (II) complexes to the efficient synthesis of $\alpha-$ or $\beta$-amino acids. Chimia. 2011;65(12):919-924. f)Popkov A, De Spiegeleer B. Chiral nickel (II) complexes in the preparation of $11 \mathrm{C}$-and 18 F-labelled enantiomerically pure $\alpha$-amino acids. Dalton Trans. 2012;41(5):1430-1440. g)So SM, Kim H, Mui L, Chin J. Mimicking nature to make unnatural amino acids and chiral diamines. Eur J Org Chem. 2012;2012(2):229-241. (h)Aceña JL, Sorochinsky AE, Soloshonok VA. Recent advances in asymmetric synthesis of $\alpha$-(trifluoromethyl)-containing $\alpha$-amino acids. Synthesis. 2012;44(11):1591-1602. i)D'Arrigo P, Cerioli L, Servi S, Viani F, Tessaroa D. Synergy between catalysts: enzymes and bases. DKR of non-natural amino acids derivatives. Cat Sci Technol. 2012;2(8):1606-1616. j)D'Arrigo P, Cerioli L, Fiorati A, Servi S, Viani F, Tessaro D. Naphthyl-1- $\alpha$-amino acids via chemo-enzymatic dynamic kinetic resolution. Tetrahedron: Asymmetry. 2012;23(13):938-944. k)Periasamy M, Gurubrahamam R, Sanjeevakumar N, et al. Convenient methods for the synthesis of chiral amino alcohols and amines. Chimia. 2013;67(1):23-29. 1)Turcheniuk KV, Kukhar VP, Roeschenthaler G-V, Aceña JL, Soloshonok VA, Sorochinsky AE. Recent advances in the synthesis of fluorinated aminophosphonates and aminophosphonic acids. RSC $A d v$. 2013;3(19):6693-6716. m)Aceña JL, Sorochinsky AE, Moriwaki $\mathrm{H}$, Sato T, Soloshonok VA. Synthesis of fluorine-containing $\alpha$ amino acids in enantiomerically pure form via homologation of Ni (II) complexes of glycine and alanine Schiff bases. J Fluor Chem. 2013;155:21-38. nBera K, Namboothiri INN. Asymmetric synthesis of quaternary $\alpha$-amino acids and their phosphonate analogues. Asian J Org Chem. 2014;3(12):1234-1260. oMetz AE, Kozlowski MC. Recent advances in asymmetric catalytic methods for the formation of acyclic $\alpha, \alpha$-disubstituted $\alpha$ amino acids. J Org Chem. 2015;80(1):1-7. pHe G, Wang B, Nack WA, Chen G. Syntheses and transformations of $\alpha$-amino acids via palladium-catalyzed auxiliary-directed sp3 C-H functionalization. Acc Chem Res. 2016;49(4):635-645.

5. a)Qiu W, Gu X, Soloshonok VA, Carducci MD, Hruby VJ. Stereoselective synthesis of conformationally constrained reverse turn dipeptide mimetics. Tetrahedron Lett. 2001;42(2):145-148. b)Soloshonok VA, Ueki H, Tiwari R, Cai C, Hruby VJ. Virtually complete control of simple and face diastereoselectivity in the Michael addition reactions between achiral equivalents of a nucleophilic glycine and (S)- or (R)-3(E-Enoyl)-4-phenyl-1,3-oxazolidin-2-ones: practical method for preparation of $\beta$-substituted Pyroglutamic acids and prolines. $J$ Org Chem. 2004;69(15):4984-4990. c)Röschenthaler G-V, Kukhar VP, Kulik IB, et al. Asymmetric synthesis of phosphonotrifluoroalanine and its derivatives using N-tertbutanesulfinyl imine derived from fluoral. Tetrahedron Lett. 2012;53(5):539-542.

6. a)Soloshonok VA, Ohkura H, Yasumoto M. Operationally convenient asymmetric synthesis of (S)- and (R)-3-Amino-4,4,4trifluorobutanoic acid. Part II: enantioselective biomimetic transamination of 4,4,4-Trifluoro-3-oxo-N-[(R)-1-phenylethyl) butanamide. J Fluor Chem. 2006;127(7):930-935. b)Shibata N, Nishimine $\mathrm{T}$, Shibata $\mathrm{N}$, et al. Organic base-catalyzed stereodivergent synthesis of (R)- and (S)-3-amino-4,4,4trifluorobutanoic acids. Chem Commun. 2012;48(34):4124-4126. c)Soloshonok VA, Gerus II, Yagupolskii YL, Kukhar VP. Fluorine-containing amino acids. III. $\alpha$-Trifluoromethyl- $\alpha$-amino acids. Zh Org Khim. 1987;23:2308-2313.

7. For representative papers, see:a)Yamada T, Okada T, Sakaguchi $\mathrm{K}$, Ohfune Y, Ueki H, Soloshonok VA. Efficient asymmetric synthesis of novel 4-substituted and configurationally stable analogs of thalidomide. Org Lett. 2006;8(24):5625-5628. b)Tang X, Soloshonok VA, Hruby VJ. Convenient asymmetric synthesis of enantiomerically pure $2^{\prime}, 6^{\prime}$-dimethyltyrosine (DMT) via alkylation of chiral nucleophilic Glycine equivalent. Tetrahedron: Asymmetry. 2000;11(14):2917-2925. c)Soloshonok VA, Cai C, Hruby VJ. A practical asymmetric synthesis of enantiomerically pure 3-substituted pyroglutamic acids and related compounds. Angew Chem Int Ed. 2000;39(12):2172-2175. d)Soloshonok VA, Tang X, Hruby VJ. Large-scale asymmetric synthesis of novel sterically constrained $2^{\prime}, 6^{\prime}$-dimethyl- and $\alpha, 2^{\prime}, 6^{\prime}$ trimethyltyrosine and -phenylalanine derivatives via alkylation of chiral equivalents of nucleophilic Glycine and alanine. Tetrahedron. 2001;57(30):6375-6382.

8. aSorochinsky AE, Aceña JL, Moriwaki H, Sato T, Soloshonok VA. Asymmetric synthesis of $\alpha$-amino acids via homologation of Ni (II) complexes of glycine Schiff bases; Part 1: alkyl halide alkylations. Amino Acids. 2013;45(4):691-718. b)Sorochinsky AE, Aceña JL, Moriwaki H, Sato T, Soloshonok VA. Asymmetric synthesis of $\alpha$-amino acids via homologation of $\mathrm{Ni}$ (II) complexes of glycine Schiff bases. Part 2: Aldol, Mannich addition reactions, deracemization and $(\mathrm{S})$ to $(\mathrm{R})$ interconversion of $\alpha$ amino acids. Amino Acids. 2013;45(5):1017-1033. c)Aceña JL, Sorochinsky AE, Soloshonok VA. Asymmetric synthesis of $\alpha$ amino acids via homologation of $\mathrm{Ni}$ (II) complexes of glycine Schiff bases. Part 3: Michael addition reactions and miscellaneous transformations. Amino Acids. 2014;46(9):2047-2073. d) Wang Y, Song X, Wang J, Moriwaki H, Soloshonok VA, Liu $\mathrm{H}$. Recent approaches for asymmetric synthesis of $\alpha$-amino acids 
via homologation of $\mathrm{Ni}$ (II) complexes. Amino Acids. 2017;49(9):1487-1520.

9. a)Ellis TK, Ueki H, Yamada T, Ohfune Y, Soloshonok VA. The design, synthesis and evaluation of a new generation of modular nucleophilic glycine equivalents for the efficient synthesis of sterically constrained $\alpha$-amino acids. J Org Chem. 2006;71(22):8572-8578. b)Soloshonok VA, Ueki H, Ellis TK, Yamada T, Ohfune Y. Application of modular nucleophilic glycine equivalents for truly practical asymmetric synthesis of $\beta$-substituted pyroglutamic acids. Tetrahedron Lett. 2005;46(7):1107-1110.

10. a)Han J, Jean M, Roussel C, Moriwaki H, Soloshonok VA. Chromatographic approach to study the configurational stability of $\mathrm{Ni}$ (II) complexes of amino acid Schiff bases possessing stereogenic nitrogen. Chirality. 2019. https://doi.org/10.1002/ chir.23059 b)Zhang W, Ekomo RE, Roussel C, et al. Axially chiral Ni (II) complexes of $\alpha$-amino acids: separation of enantiomers and kinetics of racemization. Chirality. 2018;30(4):498-508. c)Vanthuyne NC, Roussel C. Detectors for the study of unusual phenomena in chiral chromatography. Top Curr Chem. 2013;340:107-151.

11. Munakata M, Kitagawa S, Miyazima M. Classification of solvents based on their coordination power to nickel (II) ion. A new measure for solvent donor ability. Inorg Chem. 1985;24(11):1638-1643.

12. a)Soloshonok VA, Ellis TK, Ueki H, Ono T. Resolution/ deracemization of chiral $\alpha$-amino acids using resolving reagents with flexible stereogenic centers. $J$ Am Chem Soc. 2009;131(21):7208-7209. b)Sorochinsky AE, Ueki H, Aceña JL, Ellis TK, Moriwaki H, Soloshonok VA. Chemical approach for interconversion of (S)- and (R)- $\alpha$-amino acids. Org Biomol Chem. 2013;11(27):4503-4507. (c)Sorochinsky AE, Ueki H, Aceña JL, et al. Chemical deracemization and (S) to (R) interconversion of some fluorine-containing $\alpha$-amino acids. J Fluor Chem. 2013;152:114-118.

13. Moore JL, Taylor SM, Soloshonok VA. An efficient and operationally convenient general synthesis of tertiary amines by direct alkylation of secondary amines with alkyl halides in the presence of Hünig's base. ARKIVOC. 2005;6:287-292.

14. Trapp O, Schurig V. Novel direct access to enantiomerization barriers from peak profiles in enantioselective dynamic chromatography: enantiomerization of dialkyl-1,3-allenedicarboxylates. Chirality. 2002;14(6):465-470.

15. a)Hall C, Perutz RN. Transition metal alkane complexes. Chem Rev. 1996;96(8):3125-3146. b)Richens DT. Ligand substitution reactions at inorganic centers. Chem Rev. 2005;105(6):1961-2002. 